\title{
The Aesthetics of Sports Photography
}

\author{
SigRID LIEN
}

When reading newspapers there are some pages I usually just quickly leaf through - the sport pages. This is in part because the photographs that accompany the reports do not yield an arresting experience. Although a handball enthusiast, not once have I ever been struck by photo-journalistic spreads of the sport. The aesthetic experience of the game and the joy and excitement of seeing the individual players' agile movements, easily fuse into complete patterns that potentially culminate into magnificent goals - naturally not all this can be distilled into a single still photo. Nevertheless, it seems like a long dry spell between inspired cavortings and moments of surprise, at least as far as sports photography is concerned. Sports report photography is a pictorial genre with a very conventionalised profile, engendering the impression that if you've seen one photo you've seen them all.

This being the case, I was struck a few years back when I came upon some sensational, aesthetically and challenging photographic motifs of athletes. I "discovered" these in recently published works about the avant-garde art of the Russian Revolution, yet soon found that these photos had originally been part of a context of sports reporting. It was not just the aesthetic qualities of the pictures that woke my attention; I was also arrested by their great prevalence within Russian avant-garde aesthetics as a whole. In the context of sports, 'avant-garde' is in itself a surprising notion, especially seen in relation to contemporary avant-garde culture, where 'sport' and 'avant-garde' are generally thought to be incommensurable entities. In contrast to Russian sports photography, which was a product of the activity of what even then was well-known - experimental artists, the originators of contemporary sports photographs are relatively anonymous professionals.

In this paper I will examine the aesthetics of sports photograph by contrasting two different instances of this pictorial genre: the photographic idiom we find in today's sports reporting in Norway and that of the Russian avant-garde. My intention is to show how these have their respective origins in different conceptions of sports in general, the role of sports in society, art, the significance of aesthetics, and finally how they are based on different understandings of photography as a medium for expression. My goal is to set a very noticeable yet little esteemed niche of the visual culture of our own time into a historical perspective, and in doing so (with a strategic move that is in fact similar to the Russian avant-garde aesthetic) hopefully make strange that which is all too well known. 


\section{Pictorial Examples}

To begin, let's look closer at these different forms for sports photography. I have chosen two examples I think are representative for the respective photo-aesthetical approaches: a black and white photo from 1938, taken by the Russian photographer Alexandr Rodchenko, found in a large catalogue of photographics ${ }^{1}$ (ill.1), and a photo from an article in the sports pages of one of Norway's largest daily newspapers, Bergens Tidende, from Friday 13.07.2001 (ill. 2).

In the catalogue where Rodchenko's photo is presented, its title is given in English: On the Parallel Bars. We see a male gymnast, an anonymous athlete with his face hidden by the one arm, performing an exercise on the bars. The picture is clearly taken out doors. In the upper right corner it is possible to glimpse vague contours of architecture. The man executing a supple handstand is neutrally clothed in black cloth shoes and wide trousers of the same colour; a loosely tied belt is fastened about his waist. His bare upper torso with its taught muscle play accentuates his athleticity.

The gymnast's body fills the entire picture plane and the tension in his body creates a tight diagonal composition stretching from right to left. With only a tiny fragment of the parallel bars visible in the lower right corner - a marked contrast to the dominant diagonal structure - the photographer has chosen to see his motif from a very low angle and thus strengthen the impression of dynamic movement. The low perspective does not give us a horizon by which to anchor the figure in a space or a landscape. In other words, there are no pictorial elements between the floating body and the infinite sky. The strongly stylised composition, black and white colour, the conspicuous absence of "contextual clues" - for example a crowd of viewers, technological objects, clothing or tex-

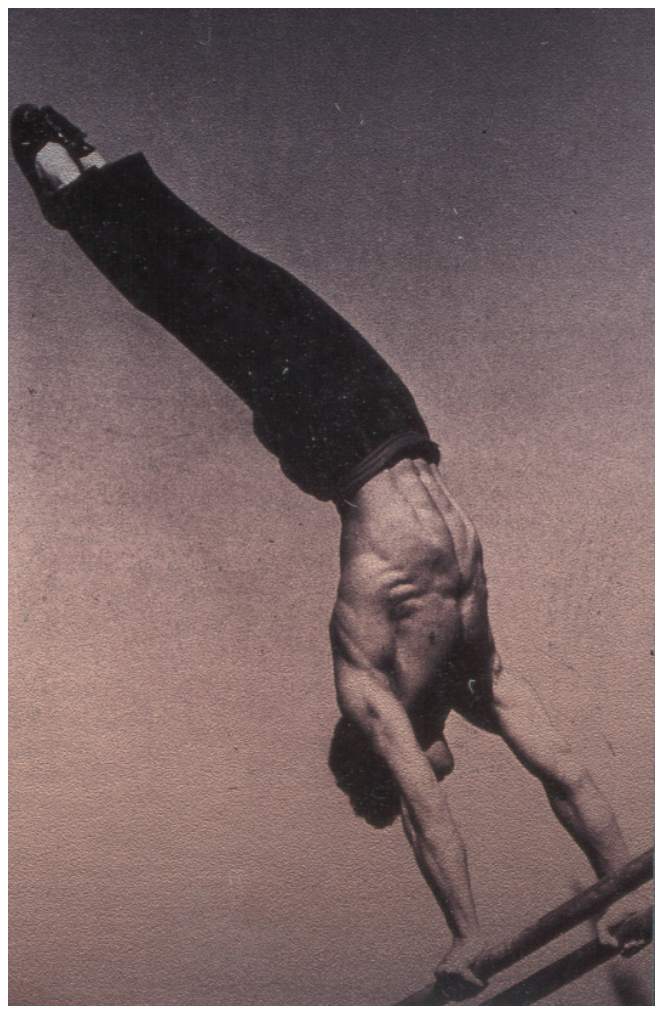

Alexandr Rodchenko, On the Parallell Bars, 1938, from Simone Philipi (ed.) $20^{\text {th }}$ Century Photography. Museum Ludwig, Cologne, Tauschen, Cologne 1996, pp. 545. 
2 .

Rune Sævig, Sports reportage photograpy, Bergens Tidende 13.07.2001.

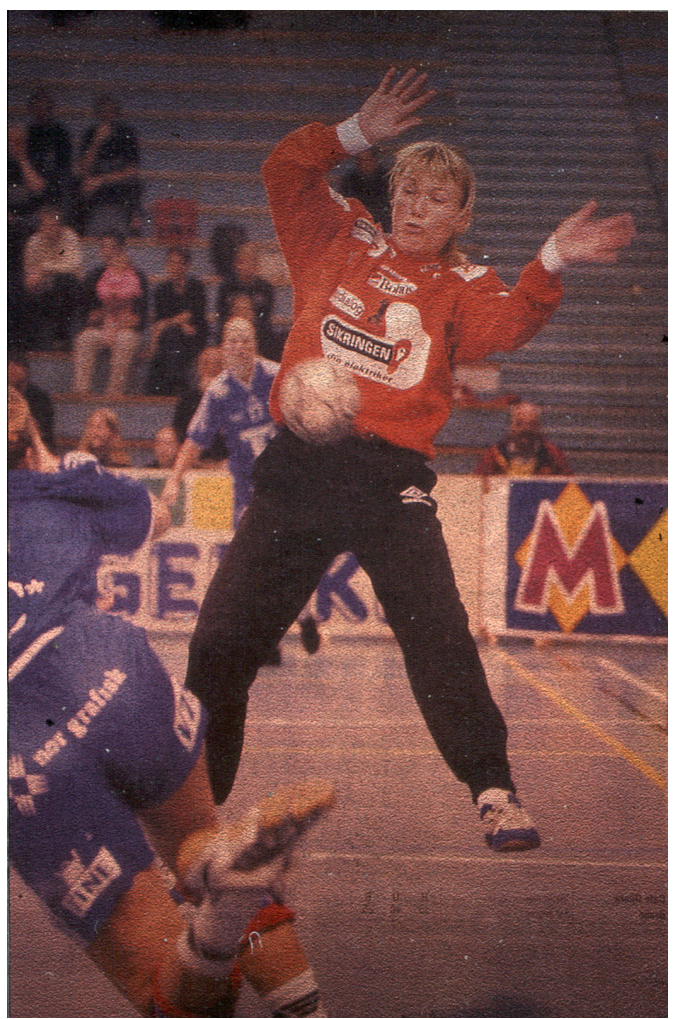

tual elements such as advertisements -infuses the picture with an almost classical character.

By contrast, my second pictorial example is anchored in a richly detailed context. It is not a museal object or published in a catalogue far from its "original home". We can view this photography in its first context of use: accompanying a text in a newspaper. The photo, taken by the press photographer Rune Sævig, shows an internationally well-known and specifically named athlete in action: the Norwegian handball goalkeeper Cecilie Leganger. She is, it seems, photographed in the moment she attempts to save a shot from the corner position. Out of focus and in the left foreground, we see the corner player who still has her body twisted sideways in the direction of the goal, her throwing arm raised. The ball is on its way towards Leganger who, in the moment of the camera flash, spreads her arms and legs in a "fall-out" to the left. The focus is tellingly placed on the star's figure in the middle axis. Leganger's face is turned toward the offensive player in the foreground and her expression signals full concentration.

In fact this picture has a reverse composition to what we found in Rodchenko's photograph. The diagonal line goes from left to right: from the corner player via the ball's placement and through Leganger's laterally tilted body. The corner player cuts across the lower left and establishes a contrasting diagonal - just as the parallel bars did in the previous example. Sævig has also hunkered in a relatively low position in relation to his motif. Yet the pictorial structure is not as clear and stylised as Rodhenko's for Sævig's photograph is untidily full of details. This is not just because he uses colour film, which in this case lends a rather heterogeneous expression of strong contrasts between various colourful elements such as the uniforms and texts, etc. The amount of information is also 
significantly larger because there are a number of details which were absent in the Rodchenko photograph: other players are in the background, there is a grandstand with unevenly spread public, and to make vision even more chaotic, large advertisements lace the court rim and the players' clothes. The advertisements are conspicuous and importunate, giving the players the appearance of veritable billboards. Every potential field is utilized. Even the corner player's posterior is used as zone of aggressive advertisement for goods and services, in this case dairy products and graphic design.

Nevertheless, the reporter's text gives an indication about what is editorially intended as the most important message. It anchors the photograph of Leganger to a concrete news event (ill. 3). This is presented boldly typed in the header line atop the picture: "Will train with Tertnes". In the caption we are informed that this is an archival photo and given a truncated version of the article's contents. The gist is that now there is a possibility for the local team, Tertnes, to get back their former star player, who has for the last few years competed for a rival Oslo club: "Wants to come home: Cecilie Leganger has not hidden the fact that she longs to return to Bergen. From what BT understands, she has sent her contract to the Handball Association to find out if Bakelaget [the Oslo team] has broken it. Here she is playing for Bakkelaget against Tertnes, next week she will train with Tertnes."

After this presentation of the chosen pictorial material, we are prompted to ask what it is that, in spite of the formal compositional similarities, makes these pictures look so different. For example, why did Rodchenko choose his classically austere, aesthetically pure and informationally reductive fragment while the BT photographer presents a veritable chaos of meaningful elements? Moreover, why is Rodchenko's subject presented as an anonymous athlete while the BT photo one-sidedly presents the individual Leganger, and thus her star-status?

These questions are critical issues in the following discussion, yet I would like to first direct our attention to what is perhaps the most important feature shared by these pictures: they are both photographs. How does this bear upon our understanding of their aesthetic character?

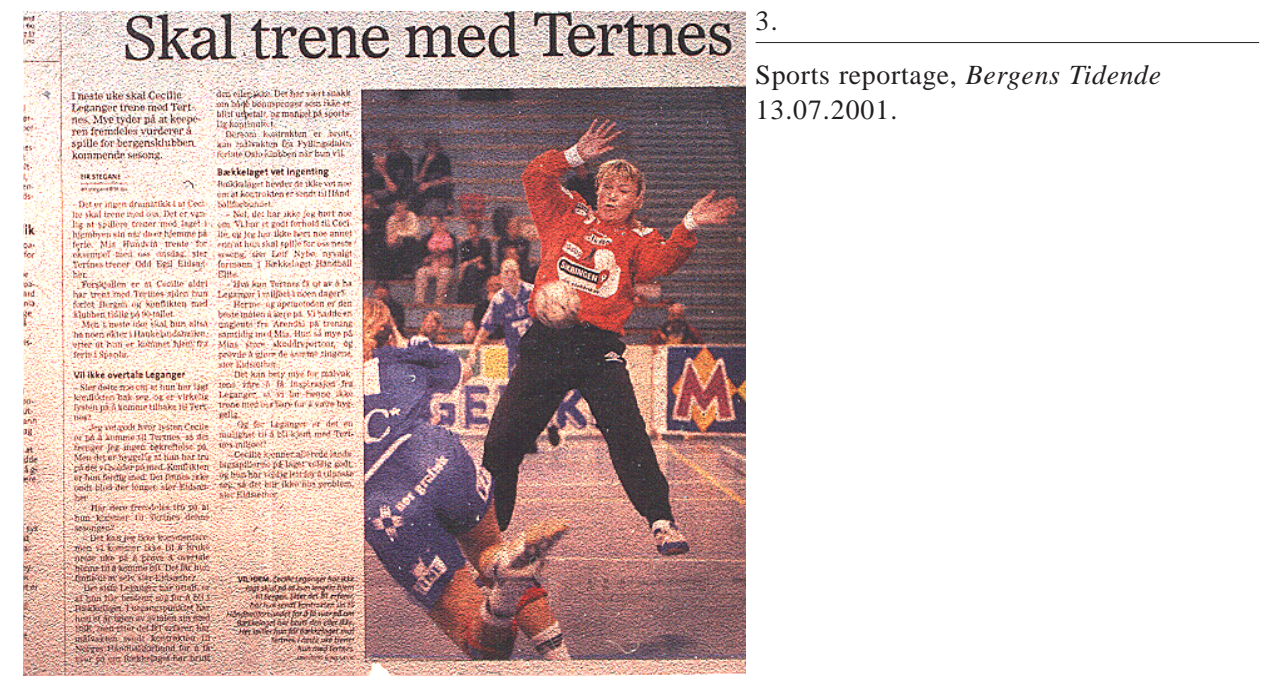




\section{A Discourse on Photography: From the Context of use to Referential Magic}

In posing the last question we land back in a discussion that has continued since the introduction of photography in the first half of the nineteenth-century, yet which still seems to be relevant. I choose to use the photo-historian Geoffrey Batchen's contribution to this discussion, in particular his doctoral thesis Burning with Desire: The Conception of Photography (1997), as a theoretical springboard from which to analyse my pictorial material. ${ }^{2}$

In this text Geoffrey Batchen takes a critical incursion into the central works of photographic theory and its various phases. In fact there were two phases to its development, the first of which was the so-called modernist formalism, the dominant art-historical agenda of the 1960's and 70's. This was well established in the USA through the work of the art critic Clement Greenberg. Yet the most important exponent for modernist formalism in photography was the French film-critic André Bazin, who, in The Ontology of the Photographic Image (written in 1945 but published in English in 1967), essentially "translated" the theories of Greenberg to photography. He did this by proffering an assumption about the "objective character" of photography as the quality that differentiates it from other media, and which is the reason why it appears as "true realism". The second main exponent of photo-formalism was the curator for photography at the $\mathrm{Mu}$ seum of Modern Art in New York (MOMA), John Szarkowski. In his writing and curatorial activities, Szarkowski sought to establish which feature of photography could be understood as specific for the medium. Furthermore, he wanted to establish what artists had successively accomplished with photography - and how their insights had contributed to extending knowledge of it as a medium? He therefore saw the history of photography as a continuous development towards increasingly deeper insight into the possibilities and limitations of the media - a perspective we also recognize from traditional art-history.

It is this understanding of photography and its history that is under attack by postmodern photographic theory, the likes of which finds the formalistic agenda both unfruitful and politically conservative. Batchen localizes the first critical voices in a number of texts published in the early 1970's: John Berger's Ways of Seiing (1972), Susan Sontag's On Photography (1977) and Roland Barthe's Image- Music- Text (French 1961, English 1977). From a theoretical foundation of Marxism and semiotics, these theoreticians contributed to developing a cultural anthropology for photography - an anthropology which comprises all possible pictorial expressions, not only photographically based art. This discourse was then incorporated into a more comprehensive criticism of modern cultural and social systems subsequently called Postmodernism. According to Batchen, although postmodern criticism has operated within a heterogeneous theoretical framework of partly competitive models (Marxism, feminism, psychoanalysis and semiotics), it has generated a remarkably consistent view of photography.

Batchen documents how this view of photography permeates texts written by the foremost photo-theorists of the 1970's and 80's: John Tagg, Allan Sekula, Victor Burgin and Abigail Solomon-Godeau. Their view is that photography does not have any static identity or singular cultural status. To the contrary, photography is understood as an extensive and dynamic field, consisting of various forms for technology, social practices and pictures. As such, this photographic field is indivisible from the institutions and discourses that choose to make use of it. Thus the history of photography is also a collective and highly differentiated history about these institutions and their discourses. For this 
reason it can also be concluded that photography does not have any continuous or united history as "itself" - beyond a selective documentation of various applied forms and effects. Furthermore, the meaning of a specific photograph will depend upon the context and time in which it is situated. A photograph can have one meaning in one context and another meaning in another context. The identity of a photograph is not pinned down to an intrinsically essential photographic quality, but, in the words of Batchen, in light of "what it actually does in the world", in other words its function.

Although Batchen sees postmodern criticism as so thoroughly convincing that it must be taken as a given, he points out that there is still a question left to be answered: What is this thing we in our culture call photography? $?^{3}$ Furthermore, is photography to be identified with its own nature or with the culture that surrounds it? Batchen argues for the usefulness of transcending the traditional polarization between an essentialist and a contextually inclined theoretical approach to photography.

He does this based upon an exhaustive empirical study of the early development of the photograph in the early nineteenth-century, and conducts a new reading of the discourses tied to the invention of photography. With reference to Jacques Derrida's concept of difference, he shows how the so-called proto-photographers presented their inventions within conceptual frameworks that defy both formalist and postmodernist attempts to identify photography from one single generative source: culture or nature, context or essence. These inventors understood the photograph as both a magical and a referential medium. I shall leave Batchen here since the most fruitful aspect of his theoretical discussion, as related to my project, is that he accentuates two things: firstly, the necessity of examining the discourses within which photography is situated, and secondly, the potential plurality of the conceptions of photography that are tied to various forms of photographic practice. I will now tentatively address these two points in relation to my chosen examples, by "reading them" with the photographic theory of the 1970's and 80's, in other words, by examining sports photography in relation to its context of use - the institutions and discoursed it is anchored in. This done, I will ask if it is fruitful to approach sports photography in light of later "neo-ontological" photographic theory, where it is stressed that the medium can be understood as both a magical and referential medium.

\section{The Applied Context of Sports Photography I: Post Revolutionary reporting of 1938}

In conducting a contextual reconstruction of Rodchenko's photograph there is one question that immediately comes to mind: How was such a photograph used in the context of reporting?

Since Rodchenko's photograph is now a museum piece, a freestanding artefact, it is difficult to give a concrete answer. Still we know that the originator was a central figure within the Russian avant-garde just prior to and after the Revolution, therefore this may be a valid context for the picture and help to further our inquiry. What then does the concept 'avant-garde' signify? What are the hallmarks of the Russian avant-garde praxis? What's more, why was an avant-guardist like Rodchenko working with photo-reportage and sports motifs?

From early in the nineteenth-century the original military context for the term 'avantguard' (a group of soldiers who form the front line in a military campaign) was already being used analogously for 'the artist as a social visionary and heroic outsider'. ${ }^{4}$ Yet 
according to Peter Bürger it was the burgeoning autonomy in the field of art and an accompanying preoccupation with its pictorial means that resulted in artists becoming increasingly isolated from contexts external to their field. ${ }^{5}$ Bürger characterizes this as the aesthetic avant-garde. What he characterizes as the artistic-social avant-garde came as a counter-reaction to the automation of art. The foremost purpose of the artistic-social avant-garde was to create art that was not purely referential to its own idiom, but that had a direct relationship to the experiences of empirical reality. ${ }^{6}$ One of the most marked artistic-social avant-garde movements in European history was precisely the Russian, reaching its apogee early in the 1920's when the Bolsheviks consolidated their power. For the first time in the twentieth-century there was a social context conceived of as a promising arena for avant-garde artists, who could now create in a way that would fuse art and life together. In order to accentuate their close affiliation to the productive life and to demystify aesthetic production, these artists chose to call themselves Constructivists or Productivists. " "The streets are our brushes - the squares our pallets" claimed Rodchenko's close friend, the poet Maiakovsky. ${ }^{8}$ Alexandr Rodchenko, who started his career as an abstract painter, was one of the most central figures in this milieu. In a photograph from 1921 we see how he let himself be portrayed standing in front of his metal constructions, clad in his self-designed outfit sewn by his wife, the designer Varvara Stepnanova (ill. 4).

Rodchenko's post-revolutionary activity can be roughly described as follows: In the years directly after the Revolution he was, in the same way as other prominent artists, intent upon developing strategies for making Constructivist painting and drawing the basis for a discourse concerning Revolutionary architecture and building design. Yet by the end of 1921 he declared that painting was "dead" and began to work with design. It was also at that time, early in the 1920's, that he became interested in photography, and from 1924 on this became his primary means of expression. From the commencement of

4.

Mikhail Kaufman, Portrait of Alexandr Rodchenko, 1921, from Victor Margolin, The Struggle for Utopia: Rodchenko, Lissitzky, Moholy-Nagy 1917-46, The University of Chicago Press, Chicago and London, 1997, pp.89.

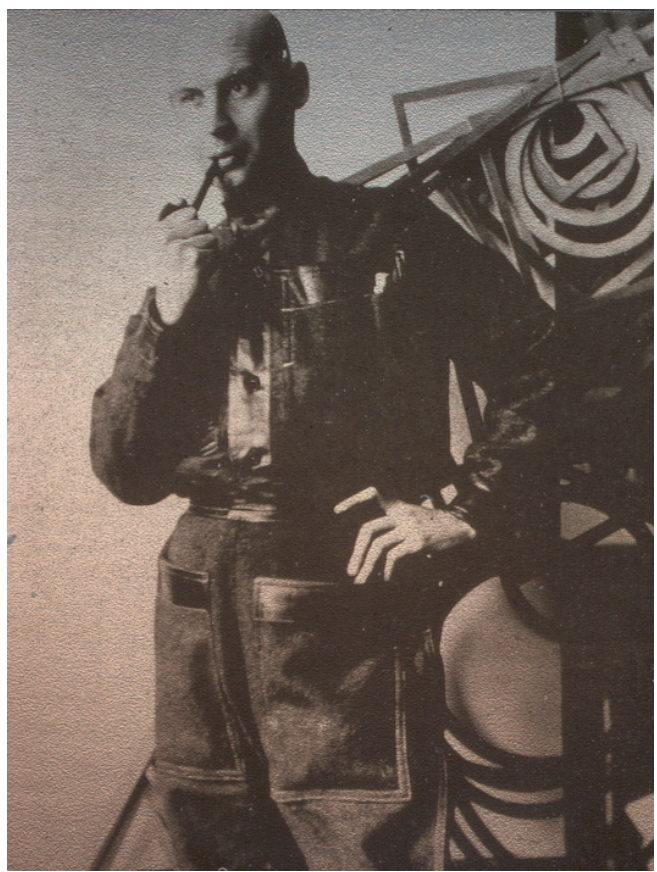


the five-year-plan in 1929, Soviet artists and designers were admonished to serve the state in a more direct way than had previously been the case. Thus Rodchenko, along with his colleagues, had to work within these new demands and limitations, which also opened up new possibilities for their patron, the Soviet state. ${ }^{9}$

What was the background for Rodchenko's and the Russian avant-garde's great interest in photography? We find one answer to this in the book on Soviet photography by the art historian Margareta Tupitsyn. ${ }^{10}$ Her study springs from the desire to correct existing writings of avant-garde history, writings which have been reticent to include photography. According to Tupitsyn, this is tied to the fact that avant-garde photography flourished at the same time as figuration gained prominence in the Soviet avant-garde milieu. In the same way as figurative painting, all photography from the middle of the 1920's has tended to be viewed as a precursor of Social Realism. Tupitsyn challenges this view by showing that photography, such as it was used in photo-montage and in so-called "straight photography" at the end of the 1920's and early 30's, was part and parcel of a discourse concerning critical issues from earlier stages of avant-garde activity: questions concerning the status of Formalism, the artist's relation to mass culture and the role of the Bolshevik regime in the development of the art world. Therefore, the function of photography in the years between 1924-27 can be viewed as the last great experiment in trying to establish an effective connection between artists, radical politics and the masses, Tupitsyn thinks. ${ }^{11}$

She describes Rodchenko's use of photography as a balance between aesthetic and political considerations. This was already manifest in his first photomontages from the early 1920's - these were works bearing witness of his reticence to mix formalistic compositions with political iconography. The artist himself was concerned with making a distinction between his photo-collages (for example illustrations for the film- and photo periodical Kino-fot and for Maikovskii's poem Pro Eto, where he conducts formal experiments inspired by Western Cubist and Dada collages as well as collages in German magazines), and his more conventional, politically iconographical photo-montages (for example the historical montage of the Revolution History of $V K P(b))$.

Meanwhile, photography was conferred with ever greater importance for the transformation of the Russian society, not least in connection with implementing the first fiveyear-plan. Here avant-garde photographers were mandated to demonstrate the superiority of their pictorial medium through the propaganda for the plan's agenda. From within this climate the critic Ossip Brik published an essay where he proffered the photography as "the true revolutionary art". However, Tupitsyn believes that Rodchenko's first pure photographs, for example the famous portrait of his mother (1924) (ill. 5) and a number of versions of his house in Miasnitskaia street in Moscow (1924) (ill. 6), were still marked by his resistance to give up modernistic methods in photography, methods that did not necessarily put documentary concerns first. Subsequently Brik criticized him, claiming that the photographs did not meet social concerns and that they were directed towards solving the problems of painting by means of photography.

It was surely in order to address this criticism that Rodchenko, starting from 1928, exhibited a pronounced interest for socialistic everyday life in his photographic works, such as we see in the photo-essay Newspaper, where he laboriously photographs the different work-processes up to the finished product - the daily newspaper. At this point in time Rodchenko was completely absorbed in photo-reportage and what he called "factograpic" representations. The enthusiasm in this work is evident from the description his close friend and colleague Boris Ignatovich gave of the so-called Soviet photography: 


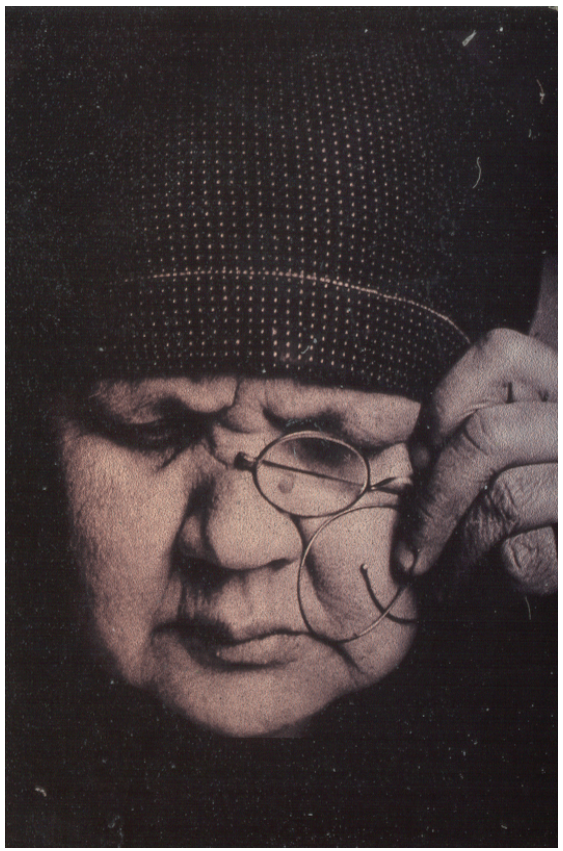

5.

Alexandr Rodchenko, Portrait of Mother, 1924, from Margarita Tupitsyn, The Soviet Photograph 1924-1937, Yale University Press, New Haven and London 1996, pp 40.

6.

Alexandr Rodchenko, The Building in Mjasnitski Street, 1925, from Grigory Shudakov, Pioneers of Soviet Photography, Thames and Hudson, London 1983, pp 51.

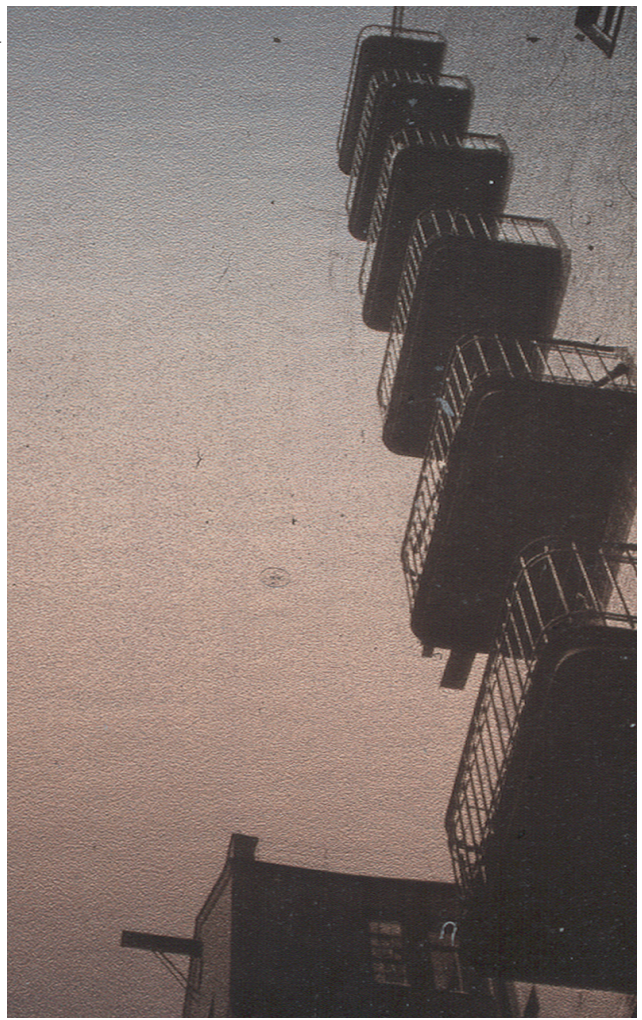


"How Soviet photography is different from Western photography: no entertainment, no tricks, no commerce; with the people and for the people; life in all its typical manifestations, with typical people - that is the material Soviet photography uses. Photography is the most contemporary realist art". ${ }^{12}$

However, if there was wide agreement that photography was the most relevant and realistic art form, there was nevertheless no consensus on how one should present the everyday situations of Soviet life. The majority of photographers divided into two camps: those who were of the opinion that innovative modernistic idioms should be applied as forms of representation, and those who saw conventional pictorial modes as best fitted to reflect the events of daily life. The first group, where we can place Rodchenko, used fragmentation in such a way that external reality appeared as an disconnected and mysterious space. Tupitsyn's example of this strategy is Rodchenko's Paving Streets (1929) (ill. 7), where he photographed the work of paving a street with a series of fragmentary photos - all characterized by Tupitsyn as "interior monologues of the productive force". ${ }^{13}$ The second group of artists, she claims, saw external reality as "a concrete, continuous entity", ${ }^{14}$ a reality that also was rendered with pictorial strategies communicating impressions of completeness and perspicuous comprehensivity. Steamroller by Arkadii Shaikhet (1931 (ill. 8), exemplifies this position, where the photographer illustrates the same work process as Rodchenko's Paving Streets, yet does it in one single snapshot.

In Tupitsyn's study, Rodchenko's pictorial strategy - his extensive use of fragments (framing) and subsequent cutting - is seen as a result of the milieu surrounding the periodical Lef (The left-wing radical art-front). She especially focuses upon the critic Tretiakov, who defended the so-called experimental "factography" in 1928. His defence shows that this milieu considered photography as something more than pure documentation or a mirroring of reality; the photographer is seen as a didactic constructor, one who helps the pictorial editor see external reality with a radical eye: "It is necessary to experiment, as far as opportunity allows, in order to resolve concrete problems"... "photography is not just a stenographer, it also explains". So for instance when a machine is photographed, its essential detail is singled out, while its other less important parts are obscured". "...To assert the primacy of the raw, unworked, unorganized fact is to threaten the practical, professional skill of the photographer". ${ }^{15}$

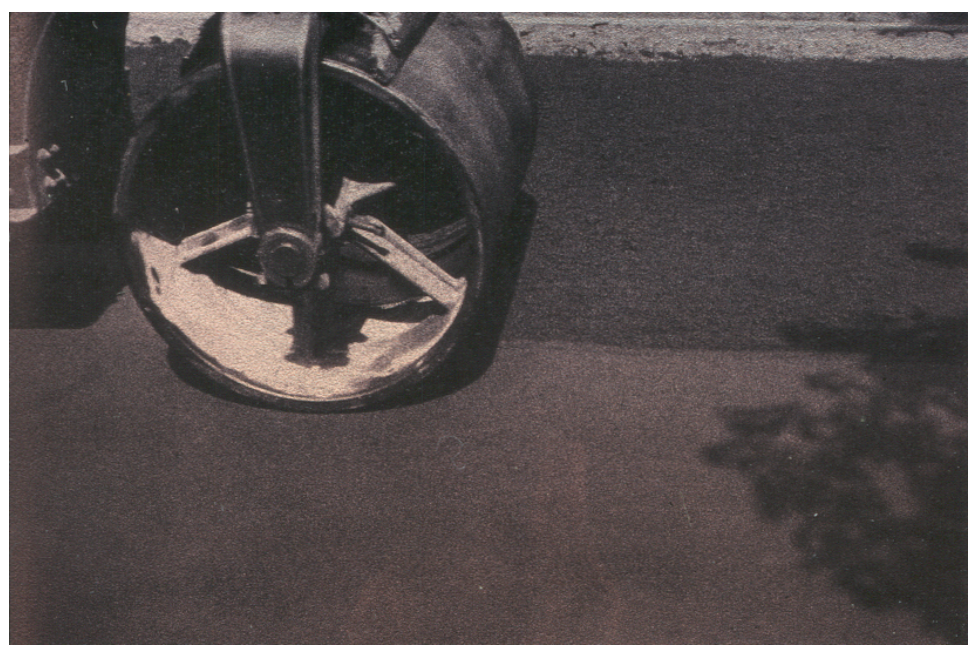

7.

Alexandr Rodchenko, Paving Streets: Leningradskoe Highway, 1929, from Margarita Tupitsyn, The Soviet Photograph 19241937, Yale University Press, New Haven and London 1996, pp 68. 


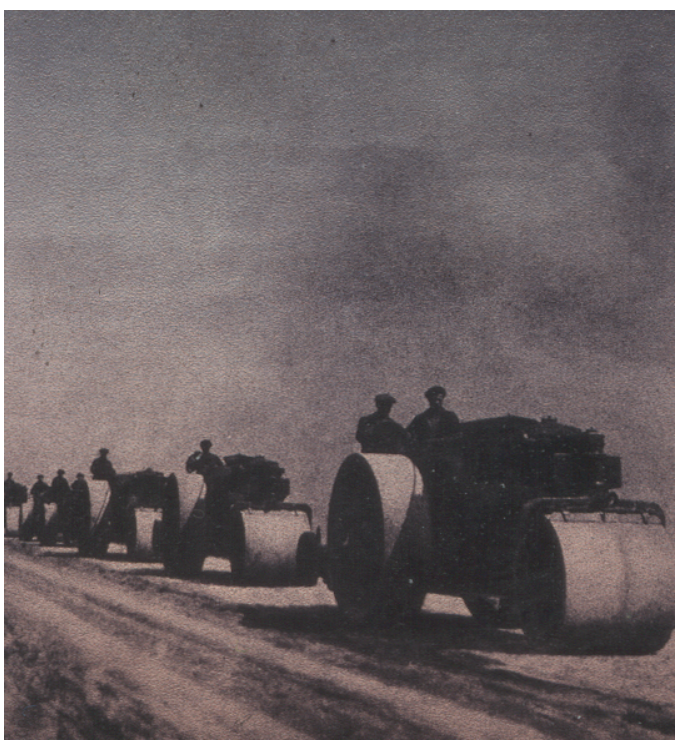

8.

Arkadii Shaiket, Steamroller, 1931, from Margarita Tupitsyn, The Soviet Photograph 1924-1937, Yale University Press, New Haven and London 1996, pp.69.

According to Tupitsyn, the de-individualized and compositionally conspicuous photographs of Rodchenko and his colleagues were able to transcend their historical specificity and as such, help the proletariat appear as united under the desire for utopia. ${ }^{16}$ From this she ties Rodchenko and his group of like-minded artists with Trotsky's idea of a worldwide Revolution, hence distancing their photographic aesthetics from Stalinism and the conception that Communism could only come to fruition in the Soviet Union.

The most important aspects of Tupitsyn's research are firstly, that she shows the artist's aesthetics as being a consequence of his ties to the radically leftwing art-front. Secondly, she regards his photographs as standing aloof from Stalinism. These are also central points for another American art-historian, Abigail Solomon-Godeau's reading of Rodchenko. ${ }^{17}$ Still, Solomon-Godeau delves deeper into the formalistic literary milieu. She shows how he, for example in the photograph The Chauffeur (1933) (ill. 9), in the same way as Roman Jacobson, seems to be focusing upon the means of photography itself. Rodchenko includes elements that reveal how the picture is constructed. It is pointed out that a great number of the artist's innovative photographs from the 1920's are marked by his rejection of the so-called natural, conventionalised mode of viewing. By using extreme vantage points (dramatically high or low perspectives), he insists that the photograph is the instrument for such seeing. Solomon-Godeau draws a parallel here to Victor Shlovsky's concept of ostranenie 'making the known unknown', thus to effectively sharpen and radicalize our view of empirical reality.

Just as Tupitsyn, Solomon-Godeau is concerned with distancing Rodchenko from Stalinism. She describes how photographic Formalism from about 1930 increasingly was under pressure from the authorities, and how Rodchenko gave in to anti-formalistic pressure in 1936, and declared himself willing to reject Formalist photography to the advantage of an idiom more thoroughly able to serve Social Realism. The avant-guarde is thus portrayed as falling victim to the Revolution's success. Solomon-Godeau draws a picture of Rodchenko as a tragic hero who survived the Revolution; wing-clipped he returned to painting in 1940, where one of his preferred motifs were sorrowful clowns: 


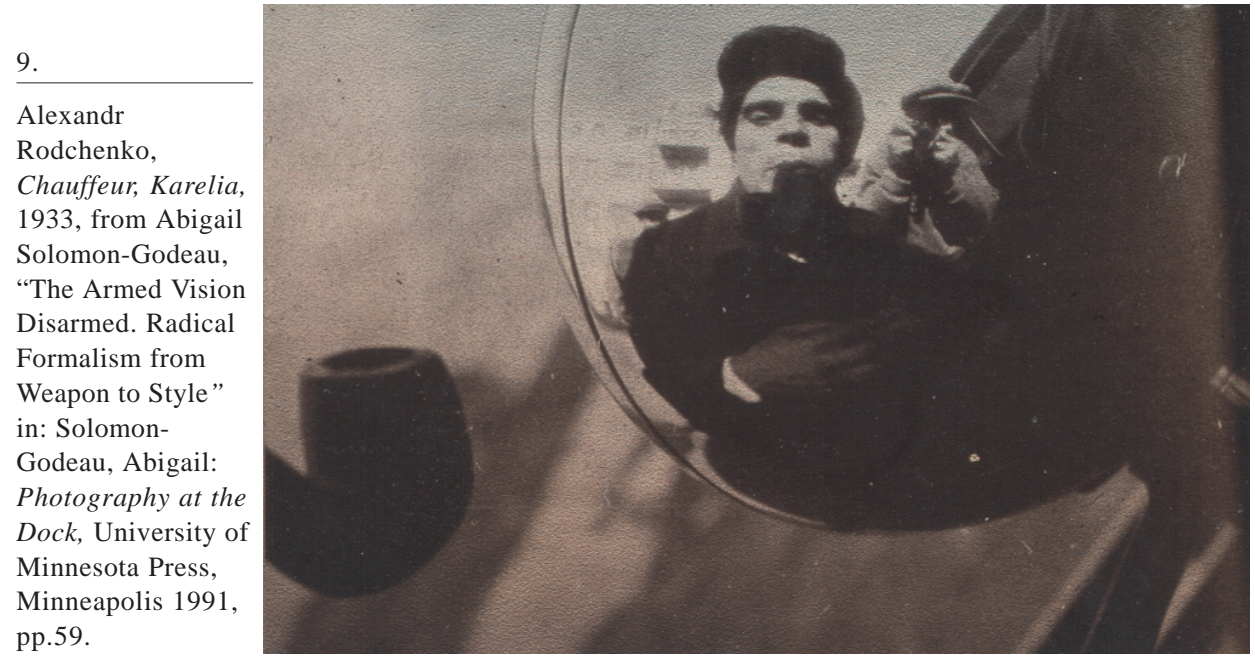

Four years later he returned to easel painting whose subjects came to include mournful clowns. In the space of about fifteen years, Russian Formalism had passed from an officially tolerated, if not sanctioned art practice, conceived as a tool in the forging of revolutionary consciousness, to an "elitist", "bourgeois", "decadent", and "counter-revolutionary" practice that condemned those who employed it to exile, silence, repudiation, or death. ${ }^{18}$

The British art historian Paul Wood (who is oriented towards cultural studies) sees this as a relatively common sort of heroic narrative - a narrative with seductive implications - but not necessarily historically correct. The implication here is that the avant-garde, who had found room in which to be creative during the chaos directly after the Revolution, is made into an object for suppression as soon as the revolutionary project is stabilized - the moment the authoritarian and artistically philistine Party shows its true colours. Wood acknowledges that while there is a kernel of truth here, this sort of heroic narrative, which in itself is ideological, has obfuscated the fact that there was continuity between the aesthetic activity just after the October Revolution and the activity of the consolidated state. ${ }^{19}$

In a study Victor Margolin has done on Rodchenko's activities during the period of 1930-41, he shows that this foremost avant-gardists from the 1920's in fact took on large government commissions after Stalin came to power. ${ }^{20}$ When examining the work Rodchenko did as one of the designers and photographers for the Russian propaganda magazine USSR in Construction, whose objective was to present a positive impression of the Soviet Union internationally, Margolin does not draw a picture of the artist's activity in the service of the magazine as an obligatory capitulation under a repressive government. Still, his study does not support the view that Rodchenko held a demonstratively positive attitude towards the Stalinist regime either. He is baffled at how the experimental avant-garde must have experienced their own contribution towards furthering Stalin's personality cult with the allotted material - small flowered folk art and conventional photography, such as in the photomontage Our country's twentieth year (1938), or in The attack on the land took place with spades and explosives (1933), which present 
canal building projects the artists must have known were built by slaving political prisoners - as heroic, Soviet deeds.

If we now return to our point of origin, Rodchenko's sports photograph from 1938; we are able to establish an explanation of its aesthetic character through contextualizing it within the Russian avant-garde's photographic practice. Furthermore, with the help of Tretiakov's formulations, we are able to attest that the photograph is far from being an ensemble of raw, unorganised facts. Rather, it is a result of a well-reflected pictorial conception. We recognize the methods of pictorial representation as described by Tupitsyn and Solomon-Godeau, and which are hallmarks of Rodchenko's photographic works: the discontinuous and mysterious depiction of space, the pictorial fragment with severely clipped objects (the parallel bars), the dramatic diagonal composition and the conspicuously low perspective. Yet the question still gone begging concerns the character of the motif: why has Rodchenko chosen a gymnast in action? Let us therefore look more closely at the conception of sports and sports exercises that reigned in the minds of the Revolutionaries.

On the report of the sports historian James Riordan, the initial impetus for Russian sports, just as for the capitalistic industrialization of Russia, came jointly from the state and from foreign interests. ${ }^{21} \mathrm{He}$ describes how the most important impulses were spawned in the relatively large foreign milieus - Germans, Englishmen, Scots, Belgians and Frenchmen - who were living in Russia before the Revolution. Just the same, this pre-Revolutionary sporting activity was not directed towards the recreational needs of the urban poor. To take part in such, and thus to have the possibility of maintaining one's physique was perceived as only for the privileged few. This being the case, the first worker's sports clubs were established at the time of the Revolutionary riots of 1905 . Riordan holds little doubt that the character of Russian pre-Revolutionary sports activities led to the later Bolshevik leaders' establishing utilitarian and politicized sports after the Revolution (in addition to ordinary ball games, several of the worker's sports clubs offered combat practice, weapon training, military drills and studies of Marxist literature). That sports would have this character was apparently also a necessity in a society where large segments of the population were illiterate, where the statistics for infant mortality were more ominous than in any other Western industrialized nation where starvation and sickness raged and ignorance of hygiene was the general rule.

Still, the new Revolutionary leaders' interest in sports was not limited to physical health. Sports were also conceived of as important for "social health". Revolutionary sports should contribute to developing the whole person: a healthy soul in a sound body. As well, there were lively discussions about the role of athletic activities in the new society. In the first years after the Revolution the leaders favoured mass sports over the more competitive types, which were associated with Western Capitalism and hero-worship - far removed from socialistic ideals. At the other extreme, Riordan describes how such activities in the following Stalinist regime came to rest on completely different ideological premises. Sports became bread and circus - a medium for Soviet propaganda: "[...] the party (that is, Stalin) was beginning to see competitive sport (with its record breaking, individual heroes, and spectator - "bread and circus" - potential) as a valuable adjunct to its impending industrialisation campaign." 22

What does this indicate about our sports photograph? That Rodchenko and his circle must have been concerned with the idea of a "post Revolutionary harmonic body and soul' is clear - not the least of which is seen in their design praxis from the mid 1920's. Sports figures were not only prominent motifs in avant-garde textiles and clothing design, 
ceramic décor, painting and photographs; Rodchenko also designed such things as chess boards and furniture for the activities of the workers clubs. Clearly 'the sportsman' was perceived as a symbol of 'the new man' and 'the new society'. Likewise the photograph represented a picture of the sportsman in action: rationality, speed and precision - in a word, modernity.

The photograph of the gymnast from 1938 was made at a time when it was difficult to be an avant-garde artist in the Soviet society - and when the conception of the ideal function of sports was in transition. Nevertheless Rodchenko shows us an anonymous sportsman from what was more than anything else considered as the sport of the masses, gymnastics. Yet the gymnast's perfect athletic physique and complete bodily control do not bear witness that this is an average citizen in a society hard hit by violent upheaval. Tupitsyn describes how Soviet photography at the end of the 1930's moved from being so-called factography to mythography. Our pictorial example clearly has features in common with the latter. She intimates that the staged character of the mythographic photograph must be seen in light of the fact that Rodchenko was only allowed limited access to photographing official events:

[...] the series of photographs he made during the various parades in 1936-38 were hardly "spontaneous". For the latter assignment he was given restricted access to record an official parade that included sport scenes, dances, a display of the achievements of the Republic's military might, and portraits of prominent political heroes. The minimalist photo-stills of the October period, with their images of people caught off guard, are here replaced by photo-pictures of romanticized dancers and virtuoso athletes. These new Soviet heroes are not simply "found" jumping in the water, blowing into a trumpet, or exercising in the morning, but are recorded performing, after days of rehearsal, on the stage of Red Square. This new photo-reportage was based on maximum expressiveness, overt theatricality and careful staging, and resulted from strictly defined commissions with specific political aims. ${ }^{23}$

Yet as we have seen, our pictorial example contains features that can be localized back in 1920's formalistic photo-aesthetics. In her thesis on Rodchenko's photography, the Norwegian art historian Vibeche Salthe has shown that his experimental photo-production seems more likely to have been rooted in the formalistic literary milieu of the magazine Lef from the 1920's rather than in a later more functional attitude. ${ }^{24}$

The photograph of the gymnast thus appears to be both paradoxical and mysterious. It can be read as a stylised, polished, Stalinist mythological representation of the ideal Soviet citizen, and yet also as an expression for artistic steadfastness - the will to hold on to an experimental pictorial paradigm. Throughout his career, even up until the late 1930's, Rodchenko was criticized for being a method-fetishist and for placing form above content. ${ }^{25}$ In that case it would have been brave of him to make photographs like this one. And perhaps this work is more than anything else to be understood as a compromising solution, an attempt to stabilize an unconventional form in a motif that could contribute to neutralizing what Rodchenko at the time the picture was taken, experienced as an insecure reality:

"These are strange times. Everyone is whispering. Everyone is afraid. It is nervewracking that everyone has friends who have been arrested. I do not know for what reason and where they are." 26 


\section{The Applied Context of Sports Photography II: The Reporting Practice of the Norwegian Daily Newspaper, 2001}

When we move our attention to our own time and the second pictorial example, the photograph of the Norwegian handball player Leganger, we suddenly find ourselves far removed from avant-garde ideas and political controversies. Still, it is relevant to ask why the picture looks as it does: what assumptions about photography and sports underpin this pictorial syntax? In the contextual reconstruction of this photograph I will use Barbara Rosenblum's pioneering work Photographers at work as a starting point. ${ }^{27}$ In her study, Rosenblum analyzes press photo material with what we can call a 'problem solving' approach: in order to cast light on the aesthetics of this material it is necessary, she thinks, to examine the behaviour and intentions of the participants in this particular practice: "What do people actually do while making objects? What procedures are employed and for what purposes? How does the practitioner foresee the outcomes of various processes? What kinds of constraints affect behavior?" 28 She establishes that the press photographer's problem solving situation is generally contingent upon two kinds of constraints, which are structural and situationally determined. The structural constraints are defined as a product of newspaper editing, for example technological concerns and patterns of task distribution, while the situational are determined according to the contingent features of the practical and social situation the press photographer finds himself in, for instance in the sports hall. Structural constraints and the specific configuration of what is situationally determined will establish a parameter for qualitative evaluation. She refers here to evaluations of creativity made by the press photographer and photo editor make, and the assumptions underlying their judgements concerning what might be a good or bad photograph.

In order to understand what could have been the structural, situationally determined and qualitative evaluations in the production of the Leganger piece, I contacted the photographer who took the picture, Rune Sævig, assistant director of the Bergens Tidende photo department. The following sketch of the context of production for the Leganger photo is based upon this interview. ${ }^{29}$ Let us first examine the structural constraints.

The Bergens Tidende photo department is relatively large, with twelve full time photographers and about as many staff who service the pictorial archive and photo-desk. About ten years ago, in the aftermath of discussions concerning the increase of staged news-photography, the department's leadership drew up a document containing the newspaper's so-called pictorial conception. In this document it says, among other things, that "Bergens Tidende shal strive for truthful pictures of pertinent and documentary interest. " ${ }^{30}$ In other words, it is the documentary function of the photograph that is emphasized in the newspaper's official photo-policy.

The task distribution amongst the photographers is based upon an informal structure where personal preferences seem to be the determining factor. Some photographers just seem to be better at sports photography and are therefore primarily given such assignments. Sævig divulges that sports photography has had rather low status in the department, which he thinks may have a connection with the uneven quality of results:

Actually sports photography doesn't have high status in contrast with general news photography and photography for feature articles. There have been some really bad pictures, and so few really good photographers. Maybe that's why. You have to work with it a long time to be good at it, to know the players, the way they play. The ones who are good at it only work with sports. 
Sævig asserts that this form for experientially based, specialized expertise is necessary in order to take good sport photographs, and is something he claims photographers working for specialized international photo-bureaus achieve more than others. To a certain extent -especially in connection with international sports events where BT does not send its own photographers - the photo department buys pictures from such bureaus, for example Reuters and Scanpix.

The newspaper coverage of sports events is elitist: the large public attractions, the city's top football (Brann) and handball (Tertnes) clubs are prioritised - although Sævig, for the record, informs me that the newspaper also reports on marginal sports activities, for example the small milieu of Sumo wrestling on the Southwest island of Stord. Sævig himself specializes in handball coverage and works relatively independently of the newspaper's appointed journalists. At the same time, it should be mentioned that the paper tries to achieve a close correspondence between text and picture. For the match that was the context of our pictorial example, it had been decided beforehand that both the photographer and the journalist should direct their attention to the visiting team's star goalkeeper:

At the game it was she [Leganger] who was the most interesting. And then it is much easier to get good pictures. Then we could concentrate on her... She's a very good motif. Very photogenic. So expressive. Actually it's a luxury to be able to focus on just one player; often you have to wait until way out into the game before you know who is outstanding.

And with this we are confronted with constraints that are situationally determined. According to Sævig there are three aspects which make photographing handball technically and aesthetically problematic: first, as a rule, there is not enough light in the sports venue. Secondly, the tempo of the game is fast and thirdly, the same players are almost always on offence. This makes it difficult to achieve a variation in motif, which again makes the pictures seem boring. The newspaper has just recently addressed the problem internally:

There was a discussion, Eir Steigane [B.T.'s handball journalist] sent an e-mail expressing irritation that the pictures were all so similar: They were all taken from the sidelines, always of offensive players who hopped in. But the problem in handball is that maybe there are two players that are very good at hopping in, and if you write about them, let's say thirty times a year, and these are the ones photographed, then it gets really boring. So it was, like, an appeal for us to think again.

The many advertisements in the sports hall represent a third moment of the photographer's repertoire of problems to solve. Advertisements on the uniforms and at courtside make it aesthetically difficult to achieve "clean" and arresting images (a problem often solved by using telephoto-lenses and by focusing closely on the object). The advertisements also seem to limit the physical availability of the motif:

In the good old days we had more freedom but that's all changed. Now if you crouch in front of an advertisement board some guard comes and chases you away. The advertisers are getting more and more powerful. I think it's gotten harder to take good pictures today than it was twenty years ago.

As well as the overriding objective of the photographs having a documentary character, the newspaper's official photo policy states that, "The pictures must reflect the surround- 
ing culture". ${ }^{31}$ What then, do the newspaper's photographs show us about the role of sports in the surrounding culture? Bergens Tidende does not show us the breadth of sporting activities, the daily exercises of amateurs and normal people, as 1920's Russian idealists tried to do - although Norwegian handball also was tied to the so-called worker's sports movement in the early days of sport. Nor does the paper give us pictures with overt political content. Rather, it conveys a picture of sports as specialized, star studded and commercially based entertainment, largely based on the sponsorial commitments of the business community.

To sum up, it can be alleged that my initial experience of the daily newspaper's sports photography has been confirmed. We have seen a lack of variation and qualitative unevenness within the genre, readily admitted by photographers and sports journalists alike. Furthermore, the inquiry concerning the picture's relationship to its own context of production has also provided a deeper understanding of why my chosen pictorial example looks as it does. We have become cognizant that the aesthetic character of sports photography is the result of a balanced compromise between editorial needs, technical/ aesthetic considerations, the framework surrounding sports organizations and sponsorial interests.

\section{Sports Photography as Mental Realism?}

If we presuppose that the identity and meaning of a photograph is contingent upon its function ("what it actually does in the world"), then the chosen photographic examples can be understood by way of their respectively applied contexts, in a historical, post Revolutionary Russian context and in a contemporary Norwegian context of reporting. This opens for an understanding of how these pictures are woven into a tight network of discourses and institutions. This notwithstanding, what does the fact that they are photographs have to do with their meaning? In this concluding section I will briefly try to suggest a more complete reading of them, a reading based upon the view of photography as a so-called mental realism. I borrow this concept from the Danish photo-historian Mette Sandbye, who, in her newly published doctoral thesis, develops Geoffrey Batchen's neo-ontological reading of photo-theory by way of analysing photo-based contemporary art. ${ }^{32}$

Her analytical approach rests precisely upon the assumption that the photograph is encumbered with what she calls a tenacious epistemology, an epistemology which still influences our perception of the photographs in spite of the Post Structuralist criticism of representation. ${ }^{33}$ In order to understand the photograph's affective meaning she directs her attention to its particular relation to time: The photograph as "that which once was", as Roland Barthes formulated it in his book Camera Lucida. ${ }^{34}$ Barthes describes how the camera, at the same time as it freezes time, also gestalts a sort of presence: an emotional and direct contact with another time or temporality. Sandbye uses works of, among others, Sophie Calles, Larry Sultan and Christian Boltanski to exemplify how art, on the basis of such a view of photography, establishes an alternative realism: not one that is based upon a mimetic representation of reality, but on the indexical character of photography - the characteristic photos have of being traces of something that has already happened. It is this form for realism she characterizes as mental realism, a realism that is both magical and referential. Sandbye shows how the mentioned artists play upon a phenomenological aspect of photography and how they exploit indexicality as an artistic strategy. 
What may have analogous value for the analysis of sports photography seems precisely to be the accentuation of the photograph as a medium of experience. It may also prove valuable to ask how the photographs can function in a dialectical, historically cognitive process. Can we, in trying to understand these two pictures, have cognisance of them as being momentary stoppages of time, as support pillars for personal memory and as experiences for cultivating identity? Which experiences of reality arise in our meeting with these photographs?

In order to identify the realistic effect of contemporary Norwegian sports photography, I will loan some reflections from Norbert Elias concerning the social function of sports in highly industrialized societies. ${ }^{35}$ According to Elias, the role of sports in modern life extends far beyond strengthening an individual's physique through his or her own activity. He points to the significance of sports as a stress stabilizer and as socially therapeutic entertainment - on par with film, dance, pictorial art, opera or crime stories. The entertainment value lies precisely in the tension generated through these activities. Elias draws an analogy between the emotional experience of a soccer game and a classical tragedy:

A tragedy enacted in a theatre, as Aristotle discovered, may evoke in an audience feelings of fear and pity closely related to those experienced by human beings who witness from nearby a real condition of others tragically caught in the snares of their lives. But the imaginary setting of the theatrical tragedy is human-made. Here humans are the creators of their own world, masters of human destiny. The heaviness of the real life is lightened, the feeling itself is purified by the mimetic symbols of music and poetry, bodily movements or masks and by the mimetic tensions experienced by those who witness human suffering and pain in the imaginary setting of a human-made tragedy [.... The spectators of a football match may savour the mimetic excitement of the battle swaying to and fro on the playing field, knowing that no harm will come to the players or to themselves. As in real life they may be torn between hopes of success and fear of defeat; and in that case too strong feelings aroused in an imaginary setting and their open manifestation in the company of many others may be all the more enjoyable and perhaps liberating because in society at large people are more isolated and have few opportunities for collective manifestations of strong feelings. ${ }^{36}$

Perhaps it is also possible to read sports reports in the daily newspaper as a sort of continuous narrative, a serial originating in sports just as Elias describes it - as an arena for the collective manifestation of strong feelings? The emotionally charged, cliché and melodramatic language in sports headlines is itself an indication of this: "The Fourth Gold Un-grasped", "It was an Offer I Couldn't Refuse", "Stord in Hangover", "Mette's Difficult Choice", "The Prodigle Savior", "The World's Best Big Sister" etc.

The report on Cecilie Leganger is just one part of a series of reports where Bergens Tidende handball enthusiasts have been able to follow the developments of the local Tertnes club almost daily: not only the more specific sports news such as team selection and game progress, there have also been articles concerning the choice of coaches, sponsor agreements and player purchase. Sports photography exists within a narrative framework where there are both heroes ("Once upon a time there was a talented player who left home to seek her fortune out in the wide world (Oslo)) and wicked villains (incompetent club managers, coaches, judges etc.). There are fairytale rewards for those who deserve it, namely the heroes (player's salary and advertisement revenues), and where 
there typically always will be a question over who gets who (Will Tertnes and Bergen get back their big player and the darling of the public?), and about who loves who (But will she really come home? Maybe she would rather stay in Oslo? Or will Tertnes get another, a new big talent [from Larvik]? - as was just publicized shortly after our chosen example). The photograph is loaded with references to reality, but also to memories and narratives tied to locally anchored sports. Therefore it is an identity-creating emotional drama for the reader. The indexical fetishism, which the contextualized photograph seems to represent, can be conceived of as a part of the narrative desire that is generated through the stories constituting this drama. Yet what about our historical example, the Rodchenko photograph, where these stories, if they ever did exist, are now lost? Which effect from reality would we be speaking of here? According to Sandbye photography offers, by way of its indexical character, "an alternative doorway into the past, into history, than the traditional narrative with its configurational, memory-based history telling; it is a dialectical picture story composed as a series of frozen points in time." She adds that this also "demands that the viewer must unfold its meaning". ${ }^{37}$ Therefore we are prompted to ask: how can we read the past in the present through Rodchenko's photography?

\section{Conclusion: The Indexical Melancholy}

We have already seen how Rodchenko's picture projects itself as a mysterious historical document. Yet it awakens other feelings in us as well: enthusiasm and melancholy. Enthusiasm is awakened because the sensational cultural products created in the Russian avant-garde's monumental push to fuse art with life have for a long time been an unknown field in cultural history: a field now being elucidated. Paul Wood has described this as an archaeological endeavour for cultural history that also casts light upon our own time:

The excavation of the full scope of the work of Rodchenko, Vertov, Klutsis, Vladimir Tatlin, Maiakovskii, and Lissitzky, not to mention the related theoretical perspectives of Osip Brik, Viktor Shklovskii, Valentin Voloshin, and others, has achieved that rare thing: the eruption of the historical work into the practical conjuncture of the present. It would not be going too far to say that a culture has been recovered - a culture, moreover, that is still revolutionary with respect to our own. ${ }^{38}$

We are awoken as well to melancholy. Its dawning is tied to the contrast so clearly presented to us, the disheartening cleft between the public life of our own time - which the sports photograph is a part of - and the radical and aesthetically creative culture that burgeoned in the first fifteen years after the October Revolution. What we see are the traces of a culture where sports were intended as a means of providing health, happiness and entertainment, not just for the chosen few but for everyone; and where artists functioned as purveyors of ideals guised as visual publicity. They did this, just as we have seen with Rodchenko, on the basis of a critical, theoretical discourse, and through a kind of photography intended to challenge the viewer's perceptual and aesthetic sensibilities - an approach that seems to be unprecedented in our own costly practice of press photography. More than anything else it is this contrast that is set in relief by the preceding comparison between Rodchenko and contemporary Norwegian sport photography. 


\section{Bibliography}

Barthes, Roland, Camera Lucida, Reflections on Photography, Fontana Paperbacks, London 1984.

Batchen, Geoffrey, Burning with Desire. The Conception of Photography, MIT Press, Cambridge, Mass., London 1997.

Bürger, Peter, Theory of the Avant-Garde, University of Minnesota Press, Minneapolis 1984.

Fer, Briony "The language of Construction", in: Briony Fer, David Batchelor, Paul Wood, Realism, Rationalism, Surrealism. Art Between the Wars, London 1993.

Margolin, Victor, The Struggle for Utopia: Rodchenko, Lissitzky, Moholy-Nagy 1917 - 1946, The University of Chicago Press, Chicago and London 1997.

Nakov, Andrei, "Stylistic Changes - Painting Without a Referent", in: David Elliott, (ed.), Alexander Rodchenko, exhibition catalogue, Museum of Modern Art, Oxford 1979.

Phillipi, Simone (ed.), 20 $0^{\text {th }}$ Century Photography. Museum Ludwig, Cologne, Taschen, Köln 1996.

Riordan, James, "Worker Sport Within a Worker State", in: Krüger, Arnd and Riordan, James (red.), The Story of Worker Sport, Human Kinetics, Champaign, Ill 1996.

Sandbye, Mette, Mindesmarker. Tid og erindring i fotografiet, Politisk Revy, Rævens Sorte Bibliotek, Copenhagen 2001.

Solomon-Godeau, Abigail, "The Armed Vision Disarmed. Radical Formalism from Weapon to Style" in: Solomon-Godeau, Abigail: Photography at the Dock, University of Minnesota Press, Minneapolis 1991.

Salthe, Vibeche Russisk kunstteori i praksis? Alekandr Rodtsjenkos 1920-tallsfotografier, Master Degree Thesis in Art History, University of Bergen 2000.

Tupitsyn, Margarita The Soviet Photograph 1924-1937, Yale University Press, New Haven and London 1996.

Wood, Paul, "The Politics of the Avant-Garde", in: The Great Utopia. The Russian and the Soviet AvantGarde 1915-32, Guggenheim Museum Publications, New York 1992.

\section{Notes}

1. Simone Phillipi (ed.), 20th Century Photography. Museum Ludwig, Cologne, Taschen, Köln, 1996, p. 545.

2. Geoffrey Batchen, Burning with Desire. The Conception of Photography, MIT Press, Cambridge, Mass., London 1997.

3. Ibid., p. 17.

4. Victor Margolin, The Struggle for Utopia: Rodchenko, Lissitzky, Moholy-Nagy 1917 - 1946, University of Chicago Press, Chicago and London 1997 p. 2.

5. Peter Bürger, Theory of the Avantgarde, University of Minnesota Press, Minneapolis 1984 pp. 20-27.

6. Ibid., p. 91.

7. The term Constructivism was borrowed from the terminology of architecture and the building industry. It had in fact been used in the Russian art milieu before the Revolution, and when applied to both sculpture and painting, it referred to works of art as "constructions where the analytical treatment of means is stressed'. This was a tradition stemming from Cézanne. However, after the Revolution the concept of 'Constructivism' took on additional layers of meaning: it was associated with the idea of 'the artist as one who constructs', i.e., one who engages in culturally useful and edifying work. This idea was seen as a contrast to the conception of 'the individualistically oriented and self-centred bourgeois artist'. See Briony Fer, “The Language of Construction”, in Briony Fer, David Batchelor, Paul Wood, Realism, Rationalism, Surrealism. Art Between the Wars, London 1993 pp. 87-167.

8. Abigail Solomon-Godeau, "The Armed Vision Disarmed. Radical Formalism from Weapon to Style" in: Abigail Solomon Godeau: Photography at the Dock, University of Minnesota Press, Minneapolis 1991 p. 57.

9. Margolin, op.cit. p.6. Literary research draws a rather complex picture of the Russian avant-garde's relationship to the Revolution and to the Soviet state. Paul Wood claims that this relationship is still an un-adequately researched theme. He shows how the existing literature describes the relationship between the avant-garde and the Revolution according to three different, but more or less explicit, sets of assumptions. Firstly, there is the assumption that the avant-garde was distanced from, or not genuinely engaged in the politics of the Revolution. Secondly, some texts hold a thesis that accentuates the avant-garde's Revolutionary commitments as a pre-condition for their many formal innovations. Lastly, there have been studies following in the aftermath of the dissolution of the Soviet Union - inquiries 
into a thus-far closed field: the relationship between avant-garde activities of the 1920's and art under Stalinism. Paul Wood, "The Politics of the Avant-Garde", in: The Great Utopia. The Russian and the Soviet Avant-Garde 1915-32, Guggenheim Museum Publications, New York 1992 pp. 1-8.

10. Margarita Tupitsyn, The Soviet Photograph 1924-1937, Yale University Press, New Haven and London 1996.

11. Ibid., p. 8.

12. Ignatiovich quoted in Tupitsyn, ibid., p. 47.

13. Ibid., p. 67.

14. Ibid., p. 67.

15. Tretiakov quoted in Tupitsyn, ibid., pp. 67-68.

16. Ibid., p. 98 .

17. Abigail Solomon-Godeau, op.cit. note 11.

18. Ibid., p. 60.

19. Paul Wood, op.cit. 1992 (note 9), p. 5.

20. Margolin op.cit.1997 pp. 163-213.

21. James Riordan, "Worker Sport Within a Worker State", in: Arnd Krüger and James Riordan (red.), The Story of Worker Sport, Human Kinetics, Champaign, Ill. 1996 p. 45.

22. Ibid., p. 56.

23. Tupitsyn op.cit. p. 156.

24. Vibeche Salte, Russisk kunstteori i praksis? Alekandr Rodtsjenkos 1920-tallsfotografier, Master Degree Thesis, University of Bergen, 2000, p. 101.

25. Tupitsyn op.cit. p. 152.

26. Rodchenko quoted in Tupitsyn, ibid p. 172.

27. Barbara Rosenblum, Photographers at work. A Sociology of Photographic styles, N. Y., London 1978. With references to Marxist art-historical writings by Meyer Schapiro, Rosenblum's goal is to elucidate the connection between social structures and stylistic expressions.

28. Ibid., p. 4.

29. The discussion took place 18.07.01

30. Øyvind Christensen, notes on the official photo policy of Bergens Tidende, May, 1991.

31. Ibid.

32. Mette Sandbye, Mindesmarker. Tid og erindring i fotografiet, Politisk Revy, Rævens Sorte Bibliotek, København 2001.

33. Ibid., p. 9

34. Roland Barthes, Camera Lucida : Reflections on Photography, Fontana Paperbacks, London 1984.

35. Norbert Elias and Eric Dunning, The Quest for Excitement. Sport and Leisure in the Civilizing Process, Basil Blackwell, Oxford 1986.

36. Ibid., pp. 42-43.

37. Sandbye op.cit. 2001, p. 138.

38. Wood, op.cit.1992 p. 4. 